Article

\title{
A Post-Development Perspective on the EU's Generalized Scheme of Preferences
}

\author{
Jan Orbie ${ }^{1, *}$, Antonio Salvador M. Alcazar III ${ }^{2}$, and Tinus Sioen ${ }^{1}$ \\ ${ }^{1}$ Department of Political Science, Ghent University, Belgium \\ 2 Doctoral School of Political Science, Public Policy, and International Relations, Central European University, Austria \\ * Corresponding author (jan.orbie@ugent.be)
}

Submitted: 13 July 2021 | Accepted: 23 September 2021 | Published: 26 January 2022

\begin{abstract}
Trade policy is generally considered to be a key leverage in the pursuit of labor norms, environmental standards, and human rights. This is even more so for the European Union (EU), which exerts an extensive market power and exclusive competences in trade while lacking a full-fledged foreign policy. In recent years, there has been a growing demand for making sustainable development provisions "enforceable" and for more frequently applying trade sanctions. Taking a post-development perspective, we interrogate the EU's enforceability discourse around the trade-sustainability nexus. We focus specifically on the conditionality behind the Generalized Scheme of Preferences (GSP). The EU GSP regime bears the "carrot" (reduced tariffs), the "stick" (preferential tariff withdrawals), and increasingly intrusive "monitoring" mechanisms. Drawing on the post-development literature, we problematize the discourses that fundamentally enframe the EU GSP conditionality regime: development through trade, performance of power, and epistemic violence. Empirically, we analyze these frames by looking at public-facing texts produced by policy elites in the EU as well as in Cambodia and the Philippines during the two most recent GSP reform cycles since 2014. We argue that the dominant discursive acts of policy elites in the EU and the two target countries congeal into a global presupposition that there is no alternative to the EU GSP regime, thereby effacing counterhegemonic perspectives and stripping emancipatory notions such as "dialogue" and "partnership" of their radical potential. This formulation demands a genuine commitment to researching with the very people the EU is intent on regulating, reforming, and rescuing to unsettle taken-for-granted views about EU trade sanctions.
\end{abstract}

\section{Keywords}

Cambodia; conditionality; development; European Union; Generalized Scheme of Preferences; Philippines; post-development; sanctions; trade

\section{Issue}

This article is part of the issue "Beyond Foreign Policy? EU Sanctions at the Intersection of Development, Trade, and CFSP" edited by Katharina Meissner (University of Vienna) and Clara Portela (University of Valencia).

(C) 2022 by the author(s); licensee Cogitatio (Lisbon, Portugal). This article is licensed under a Creative Commons Attribution 4.0 International License (CC BY).

\section{Introduction}

The use of trade policy for the pursuit of sustainable development, human rights, democracy, and wider foreign policy goals has become the subject of heated debates within the European Union (EU). In recent years, there has been a growing demand for making sustainable development provisions "enforceable" (Orbie, 2021a). A Dutch-French non-paper argued that gradual withdrawal of preferential tariffs should be considered towards trading partners that do not respect commitments made under the Trade and Sustainable Development chapters of trade agreements (Netherlands \& France, 2020, p. 1). Meanwhile, the European Commission has announced that it will review "the possibility of sanctions for noncompliance" (European Commission, 2021, p. 13). Calls for more "assertiveness" and "enforceability" in trade relations align with the goal of becoming a "geopolitical" Commission. 
While policy and scholarly debates mostly focus on bilateral trade agreements (Garcia \& Masselot, 2015; Harrison et al., 2019; Hoang \& Sicurelli, 2017; Martens et al., 2018; Oehri, 2017; Van Roozendaal, 2017), the unilateral Generalized Scheme of Preferences (GSP) has received only "modest" attention (Portela, 2021, p. 264). This "void" in the literature (Meissner, 2021, p. 91) is remarkable because, already since the mid-1990s, the EU's GSP has included a "sanctions" mechanism. Although the number of applications has been limited, the Commission's decision to more closely scrutinize Myanmar/Burma, Bangladesh, and Cambodia (EC1; see our online supplementary material for the list of coded texts corresponding to each of these unique alphanumeric identifiers) and its partial withdrawal of Cambodia's trade preferences (EC2) exemplify an ambition to be more "assertive" (EC3). The European Parliament (EP) and civil society groups also advocate a more muscular EU approach (EP1; CS1).

A key concern within the political and academic debates has been whether the EU should prioritize incentives over sanctions, or how a middle ground could be found. However, the underlying goal that the EU should use its trade power as a leverage to influence third countries and their societies remains unquestioned. In this article, we aim to critically think through such assumptions by taking a post-development perspective. Post-development as an emerging school of thought and action problematizes the "development project" and explores alternatives "beyond development." Specifically, we ask: How does the EU's GSP conditionality regime sustain the peripheralization of those it seeks to empower through developmentalist thinking?

To this end, our article attempts to contribute to a small but growing literature that problematizes Eurocentric and neocolonial tendencies in EU foreign policy (e.g., Haastrup, 2020; Keukeleire \& Lecocq, 2018; Kinnvall, 2016; Langan, 2020; Murray-Evans, 2018; Musliu, 2021; Onar \& Nicolaïdis, 2013; Orbie, 2021b; Rutazibwa, 2010; Sebhatu, 2020; Staeger, 2016). However, these writings have not yet engaged with the EU GSP regime. More broadly, post-development perspectives have to the best of our knowledge not been used to study the external action of the EU (for partial exceptions, see Bossuyt \& Davletova, 2021; Delputte \& Orbie, 2020; Horký-Hlucháň \& Szent-Iványi, 2015). Post-development has the advantage that it pays explicit attention to the development agenda of western powers towards the Global South. While the notion of the "Global South" is not an unproblematic one, we use the term here doubly as an alternative to the categories of "developing" and "least developed" countries and as a way to subvert the use of these categories in EU trade policy language.

Methodologically, we are invested in scrutinizing the dominant discourses surrounding the EU GSP conditionality regime through a frame analysis of 241 publicfacing texts produced by the European Commission (57),
EP (25), civil society organizations (26), media (87), as well as policy elites in Cambodia (18) and the Philippines (28). We caution that this article deliberately does not subscribe to the language of "cases" or "case selection." Our analysis of Cambodian and Filipino discourses on EU GSP conditionality is better read as "snapshots" (Merlingen, 2007), rather than as positivist case studies with pretensions of testing hypotheses, building theory or arriving at generalizable findings. Our snapshots point to the representation of Cambodia and the Philippines as "othered" places that are rendered open to EU development narratives and policy solutions. More specifically, we are interested in the discursive salience of GSP on and in these two countries; Cambodia has been a rare and recent object of EU trade sanctions whereas the Philippines has increasingly drawn criticisms from EU NGOs and MEPs.

We propose a post-development reading of three mutually reinforcing "frames" that are inscribed into and enacted by the EU GSP regime: development through trade, performance of power, and epistemic violence. We understand frames as ways of interpretation that help us to "select and organize raw experiential data, thereby making them meaningful. Frames are sets of taken-for-granted assumptions. These sets of assumptions shape understandings of reality" (Brandwein, 2014, p. 287). We selected relevant texts based on their salience, i.e., if their discursive orientation directly or partially addresses the EU GSP regime. We delimited the selection of these texts to the period 2014-2021 as this coincides with the latest two iterations of EU GSP reform processes. Following an emergent approach to coding, we organized these texts on the NVivo software with an emphasis on, and a close reading of, passages that are about conditionality. Our use of NVivo was not systematically aimed at quantifying and analyzing large- $\mathrm{N}$ data; rather, meaning-making laid at the core of our coding process to categorize and make textual data meaningful. To this end, the epistemology of our research design aligns with a coding process that is emergent (Elliott, 2018). Instead of using pre-configured coding protocols, we worked with a tentative set of codes and themes that we would rework throughout the research process and ultimately distill into a framework of analysis a posteriori.

In what follows, we discuss the key characteristics of the EU'S GSP conditionality regime and the analytical merits of post-development. In the empirical sections, we analyze discourses by policy elites in the EU and two target countries in Southeast Asia: Cambodia and the Philippines. We conclude with our main insights and suggestions for further research.

\section{The EU's Generalized Scheme of Preferences and Its Conditionality}

Since 1971, the EU has instituted a GSP regime that lowers tariffs for imports from target countries on a nonreciprocal basis (Gstöhl \& De Bièvre, 2017, pp. 153-162). 
This regime covers three levels of market access. First, the "standard" GSP (partly) removes custom duties for a number of products from low and lower-middle income countries. Second, the GSP+, the so-called "special incentive arrangement for sustainable development and good governance," allows duty-free access for these products from "vulnerable" countries that pledge to implement 27 international conventions related to human rights, labor rights, protection of the environment, and good governance. Third, the "Everything but Arms" (EBA) initiative implies duty-free, quota-free access for all products, except weaponry, from "least developed countries" (LDCs).

On top of this three-tiered incentive regime, two types of sanctions exist according to Regulation (EU) No. 978/2012 (2012). First, Article 15 provides that the GSP+ tariffs can be withdrawn when a country does not ratify or implement the relevant conventions or when it fails to cooperate on reporting and monitoring processes. Sanctioned countries temporarily, for all or certain products, fall back on standard GSP. It was applied to Sri Lanka (2010-2017) and Venezuela (2009-2014). Second, Article 19 foresees temporary withdrawal of preferential tariffs for all or certain products when the principles laid down in the conventions are "seriously and systematically violated" or when goods involve prison labor. Importantly, this applies to the countries that fall under the standard GSP, GSP+, and EBA schemes. This type of sanctions was applied to Burma/Myanmar (1997-2013), Belarus (2006-present), and Cambodia (2020-present).

Although EU policy language emphasizes the "withdrawal" of preferential tariffs, we interpret the abovementioned procedures as "sanctions," in line with scholarly consensus (Meissner, 2021; Portela, 2010, p. 148). Furthermore, we contend that the "granting" of trade preferences cannot be disentangled from their possible withdrawal. The "carrot" and the "stick" constitute two sides of the same coin, and it is this coin that we want to research, namely the GSP conditionality regime.

Interrogating GSP conditionality through a postdevelopment lens is relevant because it is considered the "centerpiece" (Siles-Brügge, 2014, p. 49) of the EU's trade relations towards countries in the Global South. Compared to political conditionality in other areas of EU external relations, GSP conditionality has achieved its "most perfected" form (Portela, 2021, p. 264), or as stated by a former Trade Commissioner, "it demonstrates the 'European model' of trying to dialogue, influence and push" (EC4). While extant studies have pointed to several contradictions and inconsistencies in the design and use of GSP conditionality (e.g., Meissner, 2021; Portela, 2010), few authors have questioned its underlying rationale. Extant scholarship largely follows the logic that the EU should use its power to "grant" preferences to "developing countries," often routinely referred to as "beneficiaries," who should in return comply with international standards. Studies even seem to go further than EU language in describing the conditionality as a "carrot and stick" mechanism (e.g., Koch, 2015; Orbie \& Tortell, 2009; Wardhaugh, 2013) that "rewards good behavior" and "punishes bad behavior" (e.g., Borchert et al., 2020); and one otherwise critical study at some point talks about "a really backward country" as opposed to more "advanced" countries (Kishore, 2017, p. 26). It is this kind of discursive patterns that we aim to unmask and problematize.

\section{Post-Development}

Post-development is neither a theory nor a research program. There are diverse interpretations of the concept (e.g., Matthews, 2004; Pieterse, 2010; Ziai, 2007). Post-development may rather be seen as "a set of anarchist strategies for direct action" (Schöneberg, 2021, pp. 52-53). Nonetheless, after three decades of postdevelopment thinking (e.g., Escobar, 1997; Rahnema \& Bawtree, 1997; Sachs, 1992), an emerging postdevelopment "school" might be discerned (Ziai, 2017). In this regard, the Post-Development Dictionary, which includes more than 100 entries on "transformative initiatives and alternatives to the currently dominant processes of globalized development" (Kothari et al., 2019) has been a milestone. Post-development is closely linked to postcolonial theories. While the latter theorizes the continuing material, ideological, and epistemological power structures of inequality between the Global North and the Global South, post-development perspectives engage more specifically with the questions of why this makes "development cooperation" problematic and what would be better alternatives. As such, post-development can also be read as "practiced decolonization" (Schöneberg, 2016, p. 43).

Despite the pitfalls that come with such an exercise, we think that there is some merit in trying to structure key features of post-development thinking into a pragmatic framework for analysis. While such a framework inevitably sins against the diversity that is so much cherished by post-development thinkers, by reducing a rich literature into a simplified framework, it has the advantage that it allows for a concrete analysis of specific subject matters, including the international policies of actors such as the EU. Essentially, we distinguish between the problematization of the mainstream "development project" on the one hand and the exploration of transformative "alternatives beyond development" on the other. While this arguably constitutes the key interest of post-development views, the distinction often gets blurred. Rather modest initiatives might pave the ground for more transformative activities, although the former may also jeopardize the latter by legitimizing the development project. For instance, notions such as "partnership" and "sustainability" have been stripped of their radical potential and become part of reformist development discourse. Even the buen vivir concept, which is often seen as a key example of development 
alternatives (Escobar, 2015), has been coopted by the governments of Bolivia and Ecuador, which introduced buen vivir in their respective constitutions while continuing extractivism in mining and agriculture with devastating consequences for nature and (indigenous) people. Hence, the grey area between the "development" and "post-development" fields and the dynamics of tension, co-optation (tokenism) or coalitions between them constitutes an important field of research. This ambivalent space is also where many civil society groups and activists find themselves in their day-to-day struggles and dilemmas.

Furthermore, we identify three mutually reinforcing frames that together constitute our post-development framework: vision on development, power relations, and the epistemic dimension. In the remainder of this section, we outline what each of these frames implies for the problematization of the development project and the exploration of alternatives.

First, in terms of "vision," the development project is Eurocentric by implicitly or explicitly assuming that other countries and societies should follow the Global North's (linear) path towards modernization. Other countries are not yet high on the ladder, but western actors know the way. This legitimizes (even authorizes) a paternalistic approach wherein governments in the Global North have to intervene and help lesser developed societies. "Problems" are located at the level of third countries and their leaders, while the market and growth logic are part of the solution. Failures of the development project are frequently recognized, but the typical reaction is to refine (not revisit) the development project. This is when potentially transformative idea(I)s get suffocated into mainstream discourse. Hence, there is a continuous invention and reinvention of "development alternatives" (e.g., "sustainable development," "aid effectiveness") which prevent any exploration into systemic issues. Mirroring this vision, post-development alternatives celebrate the "tapestry" of (potential) alternatives on the "good life." The Post-Development Dictionary starts with an often-quoted sentence in a Zapatista declaration: "The world we want is a world in which many worlds fit." Within the "Pluriverse," typically western dualist notions such as developed versus underdeveloped, masculine versus feminine, human versus nature, or economics versus politics, should be transcended and transformed into more relational logics. They stress the importance of local autonomy and self-reliance in harmony with the ecosystem. There is particular attention to the (potential) agency of grassroots groups and marginalized people and subaltern communities. Alternatives to capitalist modes of production (e.g., "simple living," "autonomy," "conviviality," "degrowth" or "postgrowth") are highlighted.

Second, post-development perspectives point to power relations that are historically grown and are often rooted in colonial times. Asymmetric power relations impinge not only upon material (e.g., unfair trade rules, tax avoidance) but also ideological patterns whereby the "other" (non-western) are framed as inferior because they are less developed, less civilized. The development project is also constitutionalized in the rules of multilateral organizations such as the World Trade Organizaton and the United Nations. The other is seen as the source of problems, whereas solutions should come from the west; thereby conveniently omitting the role of western elites and systemic flaws in the exploitation of humans and nature. This above-mentioned vision legitimizes development aid for, and other forms of intervention in, non-western societies. Such interventions also come with "disciplinary power" through technologies that might appear emancipatory ("dialogue," "participation," "civil society inclusion") but effectively constrain possibilities for action and thinking. In contrast, postcolonial perspectives highlight the need of what could be called "radical democracy": a rebalancing of power relations (e.g., different trade rules) and the fight against white privilege and inherently racist, sexist, speciesist, anthropocentric worldviews. The key responsibility for current problems is assigned to elites in the Global North (as well as groups and states within so-called developing countries) and systemic faults. In this sense, priority should be to change ("develop") our own societies.

Third, the epistemic dimension encompasses the universalistic vision of development. It analyzes how western interference is substantiated through knowledges (e.g., economic orthodoxies) that are considered to be neutral, technical, and objective. Post-development thinkers castigate the "epistemic violence" of research that legitimizes and de-politicizes power imbalances and defines what are (in)valid research questions, theories, and methodologies. For instance, many studies are produced on how trade serves development in terms of GDP growth and perhaps also employment, but the lived experiences of people (e.g., workers, women) and wider ecological impacts are barely considered. Existing studies thereby sustain the development industry with its specialist agencies and networks. Conversely, postdevelopment proposes "epistemic diversity" and "epistemic decolonization," with particular emphasis on local ("indigenous") knowledges. They tend to rely on interpretivist and humanistic epistemologies, with the aim of "re-politicizing" debates on the good life and an "ecologically wise and socially just world" (Kothari et al., 2019, p. xxi).

\section{EU Discourse}

\subsection{Development Through Freer Trade}

EU policymakers often stress that in 1971 the European Communities acted first among the rich world in implementing a GSP in response to a recommendation by the United Nations Conference on Trade and Development (UNCTAD). The EU GSP is feted as "the most generous scheme of its kind in the world" (EC5; also EC6; EC7) and 
the "crown jewel of European trade policy" (EP2). GSP+ conditionality is "the flagship" of EU trade policy supporting sustainable development and good governance in developing countries (EC8; EP3; EP4), demonstrating the "European model" of trying to "dialogue, influence and push" (EC4).

The main logic behind the GSP is indeed that more export opportunities should be applauded because they bring economic growth and integration in global value chains, and therefore development. In EU discourse, economic growth is often equated with "sustainable development"; the latter is sometimes further defined in terms of "poverty reduction" (EP1) or (more rarely) "employment" (EC9).

This embracement of the export-led development rationale obscures the fact that free trade entails winners in Europe and losers in so-called beneficiary countries. European importers and retailers typically lobby for lower GSP tariffs, as they are indeed "beneficiaries" of the regime. As argued by Poletti and Sicurelli (forthcoming), pressures of European importer and exporter interest groups not to jeopardize free trade partly explain the EU's cautious approach to sanctions. It would also go against the free trade logic that reigns in the Directorate-General for Trade of the European Commission (DG Trade; see also Bossuyt et al., 2020). Furthermore, an "expert" study for the Commission's mid-term review points to negative impacts of the EU's GSP on the environment, on human rights, and on land grabbing in third countries (EC10, pp. 247, 257). These flaws are backgrounded or even entirely omitted in Commission discourse. When MEPs mention them, this is mostly framed as a secondary concern that does not undermine the overall objective of trade liberalization. Nonetheless, a report for the EP admits that no direct link can be found between trade liberalization, economic growth, and poverty reduction (EP5).

In this context, ubiquitous references to the GSP's origins in UNCTAD demands must be reconsidered. EU policymakers consistently fail to emphasize that the GSP was only one relatively small element in a wider New International Economic Order (NIEO). The NIEO agenda was strongly embedded in dependencia thinking and proposed radical reforms against and beyond liberalization. Moreover, as argued by Kishore (2017, pp. 17-20), the NIEO architects objected any conditionality attached to the GSP.

To be sure, EU policymakers recognize that the impact of the GSP and its conditionality system is difficult to measure. However, this leads only to efforts to modify and refine the system by relaxing rules of origin, promoting awareness, adjusting graduation rules, fostering diversification, and, as explained below, more sophisticated "monitoring" and "engagement." Its fundamentals are not questioned.

An important implication of the export-led development logic is that it keeps the EU in a donor role and reinforces donor-recipient patterns. Since more exports are beneficial, the EU becomes the benefactor that "grants" trade preferences or "privileges" to third countries. Indeed, policymakers systematically and uncritically talk about the "granting" of "preferences" to "beneficiaries." By "offering" tariff reductions, the GSP "helps," "assists" and "supports" developing countries. As a Commission pamphlet states, "Trade has great potential to help them grow....That's why we're committed to helping them do so" (EC11). In the GSP+ context, this paternalistic pattern is reinforced through EU aid in the form of "capacity building" and "technical assistance." Development assistance will be needed to guarantee that beneficiary countries can comply with international conventions (EP1; EC12; EC13; EC14).

\subsection{A Performance of Power}

These donor-recipient discursive patterns have implications for the ways in which the EU enacts power. As the EU is granting market access to beneficiaries, it is in a position to ask something in return. GSP conditionality is indeed often framed in terms of "giving and taking": Europe offers trade privileges, and in return developing countries comply with international conventions. Otherwise, the EU can legitimately withdraw this favor.

This "power" dimension constitutes the most distinctive feature of the EU's GSP discourse. Policymakers never fail to stress the EU's formidable influence over third countries through GSP. The terms "tool" and "leverage" are frequently used. Commission officials and some MEPs hail the EU's effective power, whereas other MEPs criticize limited effectiveness. However, both seemingly opposing sides take the assumption that the EU should use market access as a leverage to influence reforms in third countries.

In terms of ideological power, the "developed" versus "developing" country distinction is obviously a core binary. The category of developing countries is further refined into LDCs (EBA), "vulnerable" countries (GSP+), and other "low and low-middle-income" ("standard" GSP). Since the mid-2000s, there has also been an understanding that economically stronger countries would negotiate a bilateral trade agreement with the EU and therefore "graduate" from GSP. This was further stimulated through the 2012 reform that removed "uppermiddle-income" countries from the GSP (Siles-Brügge, 2014). The picture that emerges from all this is a neatly quantified hierarchy of stages of development.

On the surface, these power performances seem to contradict the EU's increasing emphasis on "dialogue" with beneficiary countries and its longstanding argument that withdrawal is only a "last resort" measure. However, this so-called distinctively European approach does not undo the highly asymmetric power relations between the EU and its "beneficiaries" and may even further legitimate European intervention in third countries.

First, dialoguing is enacted within the context of a unilateral regulation under EU law and highly asymmetric 
power relations. GSP countries' political agency is even more limited than under bilateral trade agreements, where third party governments can negotiate market access and where monitoring is the responsibility of each signatory country. Specifically, GSP+ dialogues are organized in the framework of increasingly intensive monitoring exercises. Monitoring subjects GSP+ countries' compliance with international conventions under surveillance and may entail the continuation of trade preferences or the invocation of the withdrawal procedure. As indicated by the Commission, GSP+ beneficiaries "must sign a binding undertaking to...fully cooperate with the Commission in GSP+ monitoring." This is based on two "tools": a "scorecard" on the "shortcomings" to which countries "must respond," and a dialogue which also focuses on the "beneficiary's shortcomings" (EC15).

In the same vein, the Commission has started a process of "enhanced engagement" with three EBA "beneficiaries," namely Myanmar/Burma, Bangladesh, and Cambodia. This resulted from mounting pressure from the EP and civil society groups on violations of human rights and democratic principles in these countries. As with the GSP+ dialogue, this "engagement" takes place under asymmetric power relations and against the realistic threat of implementing sanctions. MEPs and civil society organizations have asked to extend these monitoring experiences to other GSP countries.

Second, statements about withdrawal being a "last resort" option "if all engagement fails" (EC16) and a "very strong nuclear weapon" (EC4, p. 18) further sustain the EU's power performance. Moreover, the burden of proof increasingly lies with GSP countries themselves. In relation to GSP+ conditionality, the 2012 reform reversed the responsibility (EC8, Art.15.2). Equally, under "enhanced engagement," EBA countries must prove adherence to their commitments. In this context, the Commission states that beneficiaries should take more "ownership" and be "more proactive" in addressing issues in the scorecards (EC17, p. 13). This exemplifies not only the co-optation of concepts such as "ownership" but also blame-shifting whereby problems are located at the level of countries in the Global South and their villain governments, whereas systemic injustices (e.g., global trade rules) and western responsibilities (e.g., regulation of multinationals) remain unaddressed in the GSP discourse. Similarly, biannual GSP+ monitoring reports focus at the national level of third countries.

\subsection{Epistemic Violence}

Epistemically, the EU has entrenched a technocratic reading of the GSP regime that uniformly gazes at many places in the Global South as "most in need" or "vulnerable" (EC18), thereby reinforcing law-like positivistic knowledge claims for their undisputed socio-economic beneficence in target countries. This epistemic violence works in a number of ways. First, as mentioned above,
EU technospeak lumps together all countries under the GSP scheme as "beneficiaries." Naming countries as such already presupposes a necessarily positive outcome and deemphasizes how the receiving end of EU largesse understands the political (in)significance of trade preferences. Relatedly, the policy design of the EU GSP regime hinges on a categorization of low-income countries as "developing" and "least developed" on the basis of World Bank indicators. DG Trade is on record confirming that this "robust" classification seeks "to depoliticise the admittance to GSP and ensure [its] objectivity and non-discrimination" (EC19). However, this naming convention de-historicizes the dark legacies of European colonialism and redraws new geopolitical boundaries, as in the case of African LDCs versus non-LDCs in the sugar trade under EBA (Lincoln, 2008). Some organizations claiming to represent voices in the Global South do critique the EU's nominal practice of othering countries, yet fail to question its underlying logic and instead succumb, for example, to "suggestions to consider Sub-Saharan Africa as a region eligible for EBA" (CS2). Furthermore, $\mathrm{GSP}+$ eligibility revolves around the idea of "vulnerability," which the EU conceptualizes as a phenomenon "due to a low level of economic diversification, and a low level of integration within the international economy" (EC20). The latter is measured through a sui generis EU definition of "less than the threshold of $2 \%$ in value of total imports" (EC21) destined to the EU marketspace. Put crudely, this means that developing countries must be "vulnerable" in part because they are not trading enough with the EU, thereby effacing global power hierarchies as well as the domestic political economy constellations behind socio-economic inequalities in target countries.

Such a Eurocentric understanding of political and social realities in the Global South points to the ways in which the EU insists on the causal power of its GSP regime to explain away non-trade transformations in the unruly places it seeks to reform. Again, studies made by the EU and its external consultants caution against the methodological difficulty of distilling the effects of trade preferences due to the presence of other plausible explanatory variables (EP6; EX1; EC12; EX2). Nevertheless, this limitation has not detracted the EU's epistemic desire to document not only the economic significance but also the social, environmental, and human rights impacts presumably arising from the GSP regime (EP6; EX2). To this end, econometric studies flanked by qualitative case study research are often used. However, these "in-depth" studies rely on indicators (EX1), advocate an "evidencebased" approach to impact assessment (EC22), or borrow heavily from secondary literature even when claiming to understand, for instance, how GSP affects female workers and entrepreneurs (EX2). What binds these positivist technologies together is their scholarly neglect of the lived experiences of the very people the EU claims to champion. 


\section{Cambodian and Filipino Discourses}

\subsection{Cambodia and Everything but Arms}

In their performance of power, EU policymakers insist that Cambodia has "severely and systematically allowed human rights violations to take place and flouted international conventions" (EC5), and at the same time claim that "we do not-and never have-envisaged trade sanctions against Cambodia" (EC23). The European Commission has emphasized that they "will provide Cambodia with every opportunity to cooperate, and will gather all necessary information" before deciding whether or not to withdraw trade preferences (EC24). Following fact-finding and monitoring missions in 2018 and 2019, the EU withdrew Cambodia's trade preferences under the EBA scheme in 2020, albeit partially so as to exempt the Cambodian garment economy. The Commission asserts that this firstever partial GSP withdrawal "addresses the human rights violations that triggered the procedure, while at the same time preserving the development objective of the EU trade scheme" (EC25).

Prior to this eventual political decision, the dominant discourse in Cambodia in relation to the threat of EU preferential trade withdrawal clearly replicated the EU's developmentalist framing of GSP. The Cambodian business community stood united in articulating the counterproductive outcome of GSP withdrawal against poverty alleviation ( $\mathrm{KH} 1$ ), the need to further diversity Cambodia's export profile ( $\mathrm{KH} 2)$, and a "near collapse" of the country's feminized garment economy already suffering under the wrath of Covid-19 (KH3; $\mathrm{KH} 1$ ). Nevertheless, foreign and local business associations viewed the EU's move to instigate the EBA withdrawal procedure "as an opportunity to initiate further structural reforms that strengthen legal compliance and reduce unfair competition, which will help to accelerate the diversification of Cambodia's economy, export markets and sources of investment" (KH2).

For its part, the Cambodian state explicitly made references to the "positive" influence of EU trade policy on Cambodia's development efforts:

By implementing these withdrawal measures, the European Commission takes the risk of negating twenty year's [sic] worth of development efforts which the Government had persevered to pull millions of women and men out of poverty and as a result such decision would nullify the enormous positive impact of the European policy from which Cambodia has benefited so far. (KH4)

Whereas the EU asserts an intransigent worldview of its GSP regime as a depoliticized development device, Cambodian elites tend to question the epistemic violence underpinning this worldview. As a mechanism for promoting international commerce, EBA "should not be used as a weapon to kill Cambodian people" according to the Cambodian interior minister (KH5). State discourse also stresses that Cambodia "is not under the trusteeship of foreign institutions" (KH6) and sees the negative conditionality attached to the EBA scheme as a pretext to justify interference in Cambodia's internal politics (KH7, KH8). A government spokesman put it even more strongly: "The EU is not our boss, nor is Cambodia its colony" (KH9).

Yet, despite criticizing the neocolonialism lurking behind the EU GSP regime, the economic "benefits" arising from EBA remain foregrounded (KH7), thwarting any serious political discussion around alternatives to development and instead stressing the language of "partnerships":

We are partners so we will continue our dialogue as such. In this manner, we talk and make joint assessments....In this partnership, the EU cannot dictate us to do this or that. They express their concerns and we tell them what we have done [to address them]. (KH9)

Enfolded into this dialogic approach to EBA-related issues are the positions of business groups and trade unions. For the Cambodian business community, engagement and dialogue are the preferred avenues or "effective tools" through which EU concerns on human rights and democratization should be addressed ( $\mathrm{KH} 2 ; \mathrm{KH} 1)$. Business groups also reminded the $\mathrm{EU}$ that it has been the mechanisms of engagement and dialogue with Europe that catalyzed the "immense progress" Cambodia has witnessed over the last two decades (KH10). Stakeholders argued that EBA withdrawal could undermine the partnership model between Cambodia and the International Labour Organization on improving labor rights and working conditions and "unintentionally erase" years of progress on these areas, including a high unionization rate of $80 \%$ in the garment industry (KH1). For their part, the Trade Union Negotiation Council maintained that "engagement between employers and trade unions on a collective agreement would be a positive signal to the EU of the commitment of the parties involved in practicing dialogue" (KH11). At any rate, the overarching emphasis on dialoguing has as its ultimate end the maintenance of the status quo around GSP.

\subsection{The Philippines and GSP+}

Since 2014, the Philippines has been subjected to the EU's performance of power through the GSP+ regime. The "plus" in GSP+, of course, signifies that an eligible "vulnerable" country agrees to implement 27 international conventions in exchange for better market access to the EU. Under the Duterte government, the Philippines has been on the cusp of losing GSP+ concessions for its "continuing violations of civil and political rights" (EC26), which allude to the government's "war on drugs," imprisonment of political opponents, attacks against the press, and calls to reinstate capital 
punishment. Furthermore, the Filipino fisheries economy has particularly garnered prominent attention from EU actors who complain about the sector's lax labor conditions (CS4) and misfit with the "good fisheries governance in the EU" (EP7). Some European civil society groups opposed the Philippines' accession to the GSP+ regime, fearing this "would distort the GSP essence" and "destabilise the community preserved tuna market" in the EU (CS5).

Amid threats of GSP+ withdrawal, Filipino business and political elites have used a developmentalist framing of GSP+ in a bid to preserve their preferential access to EU markets. For industry groups, losing GSP+ would dampen the country's export competitiveness ( $\mathrm{PH} 1)$ and sound a death knell for Europe-facing producers "as the coronavirus pandemic is bleeding any remaining capital from exporters" (PH2). The European business community in Manila warned that workers in the agriculture and manufacturing sectors would ultimately be the ones shouldering the brunt of the EU's decision to lift trade incentives ( $\mathrm{PH} 2$ ). Opposition politicians relied partly on the GSP+ to lambast the Duterte government's thrust to bring back the death penalty, arguing that losing preferential market access to the EU would be damaging to the country's economic growth story (PH3). Meanwhile, the Filipino government defended "the Philippines' fitness to keep trade privileges" (PH4) by further expanding GSP+ utilization across the archipelago and intensifying bilateral dialogue with a view to signing a free trade agreement (FTA) with Brussels (PH5). Relatedly, in the congressional deliberations on the proposed Philippine-EU Cooperation Agreement, the chair of the Senate Foreign Affairs Committee expressed that this partnership "will bolster our status as a [GSP+] beneficiary country" and propel ongoing FTA negotiations (PH6).

In the wake of the EP resolution calling for the immediate initiation of the GSP+ withdrawal procedure against Manila, Malacañang officialdom accused the EU as "the biggest contributor to the violation of the right to life in the Philippines" and slammed the move by "former colonial masters" (PH7) should they revoke trade concessions at the height of a global health pandemic. The Speaker of the House of Representatives denounced the EP for its "outright interference...in the purely domestic matters of the Philippines" (PH8). The Philippine Exporters' Confederation decried the politicization of trade matters based on perception (PH9).

Yet, beyond these diatribes, the idea that the EU GSP regime, as a site of epistemic violence, points to new topographies of neocolonial intervention remains undisputed in practice. This insight seems lost even on "radical" civil society organizations that fully support the EU's policy of withdrawing trade incentives from countries flouting their human rights obligations (PH10; PH11). Regarding EU concerns about the Filipino fisheries industry, legislators admit in the open that the Philippine Congress has strengthened its governance framework in response to the EU and to comply with international stan- dards against unsustainable fishing ( $\mathrm{PH} 12$ ). Reflecting this acquiescence to the philosophy behind the EU GSP conditionality, a congressional bill has been introduced to ensure the Philippines' compliance with international conventions "as a condition precedent to enjoy our trade preferences" (PH13). Indeed, this proposal feeds into ongoing monitoring missions to the Philippines as well as high-level dialogues on good governance, rule of law, and human rights. Here, the addressee of political (in)action appears to be orientated around the EU as a trade power, not towards or with the Philippine public. In other words, it is the EU that impels ideas for change, disregarding the epistemic role of Filipinos who have clamored for social transformation long before "scorecard issues" concerning the Philippines have been made subject to GSP+ monitoring.

\section{Conclusion}

The concepts of "development" and "developing countries" are increasingly contested. This awareness is reflected in the Von der Leyen Commission, with Jutta Urpilainen being the "Commissioner of International Partnerships" and the Directorate-General for International Cooperation and Development (DG DEVCO) being renamed into the Directorate-General for International Partnerships (DG INTPA). Surprisingly, however, the goal of the EU's GSP regime is still quite frankly the "development of developing countries" (ECO1). As a global trade power, the EU exploits its GSP conditionality system to govern economic, political, and social transformations in the so-called "developing" world. From a post-development lens, the given nature of the thinking and technologies that sustain the EU's policy scripts of granting and withdrawing trade preferences from "beneficiaries" needs to be provincialized for this worldview "circumscribes our understanding of what is politically possible" (Sabaratnam, 2013, p. 5). Although it is beyond the scope of this article to discuss at length the contours of other politically possible worldviews, we believe that the intellectual currents of postdevelopment and/or degrowth propel credible alternatives to the prevailing developmentalist imaginaries of the EU GSP regime. For instance, ideas that explicitly link post-development and degrowth question the doctrine of growth and economism, acknowledge the coexistence of plural worlds based on ecological integrity and social justice, and mitigate the cooptation of those with little or no political agency by the more powerful (Escobar, 2015). In the context of the climate crisis, degrowth becomes more and more relevant as it puts emphasis on:

Reducing the material energy throughput of the economy to bring it back into balance with the living world, while distributing income and resources more fairly, liberating people from needless work, and investing in the public goods that people need to thrive. (Hickel, 2021, p. 206) 
EU discourse on GSP conditionality clearly replicates traditional developmentalist thinking. First, the vision behind GSP sanctions and incentives shows that the EU aims to help developing countries through marketbased solutions and incremental changes within the GSP regime. Second, the GSP is presented as a key tool for influencing third countries based not only on carrotand-stick conditionality but also on ideological and disciplinary power mechanisms. Third, this project is underpinned by seemingly technical and objective knowledge in the form of depoliticized language and scientific studies, sidelining other ways of understanding the social and political world. Overall, historically grown power asymmetries and alternatives to development are silenced.

In Cambodia and the Philippines, political actors deploy anti-colonial sentiments when faced with threats of EU trade sanctions. However, this is not embedded in a decolonial or post-development discourse. Politicians, businesspeople, and civil society organizations in both target countries undeniably embrace developmentalist scripts as performed by the EU trade policy establishment itself. Cambodian and Filipino policy elites narrate their economic growth stories in relation to the "benefits" their countries get under the GSP regime. The notion of GSP withdrawals is either seen by various actors as injurious to the interests of poor workers or as nonetheless necessary in order to toe the line of unruly governments. Otherwise, the continuity of dialoguing and monitoring is the preferred modality of meeting EU "scorecard" concerns. The dominant discursive acts around EU GSP conditionality all congeal into a global presupposition that there is no alternative to the EU GSP, thereby asphyxiating possible counterhegemonic perspectives. Notions such as "partnership" and "sustainability" have been stripped of their radical potential and become part of a reformist development discourse. It is crucial to emphasize that, in this contribution, there is an absence of "grassroots" views on the EU GSP conditionality, mainly because of the impossibility to commit to a genuinely enthographic field research at the time of writing. More importantly, we fear that such groups lack the necessary means to participate in, or may be methodologically neglected by, the GSP reform process. This lacuna, finally, leads us to stress a possible avenue of further research into the lifeworlds of the very people the EU GSP regime is intent on regulating, reforming, rescuing. Staying true to the spirit of post-development thought, learning from and with the targets of EU trade preferences with an ethnographic sensibility to their thoughts and experiences would be another pragmatic, more humanistic way to unsettle taken-for-granted elitist views about EU trade sanctions.

\section{Acknowledgments}

We are grateful to all participants of the ECPR Joint Sessions Panel "Designing Sanctions: The European Union in Regional and International Affairs" (May 2021) and the ECPR General Conference Panel "The Usual Suspect? Drivers, Attitudes and Politics of Contestation of EU Trade Policy" (August 2021), and particularly to Clara Portela, Katharina Meissner, Martijn Mos, Dirk De Bièvre, Magdalena Gora, Camille Nessel, and Patricia Garcia-Duran, for insightful feedback on previous versions. We also thank Elke Verhaeghe for her helpful advice on NVivo coding.

\section{Conflict of Interests}

The authors declare no conflict of interests.

\section{Supplementary Material}

Supplementary material for this article is available online in the format provided by the authors (unedited).

\section{References}

Borchert, I., Conconi, P., Di Ubaldo, M., \& Herghelegiu, C. (2020). The pursuit of non-trade policy objectives in EU trade policy (Working Paper EUI RSCAS 2020/26). European University Institute. https://cadmus.eui. eu/handle/1814/66882

Bossuyt, F., \& Davletova, N. (2021, May 20). Communal self-governance as an alternative to neo-liberal governance: Proposing a post-development approach to EU resilience-building in Central Asia [Paper presentation]. COMPASS Work in Progress Seminar (WiPS).

Bossuyt, F., Orbie, J., \& Drieghe, L. (2020). EU external policy coherence in the trade-foreign policy nexus: Foreign policy through trade or strictly business? Journal of International Relations and Development, 23(1), 45-66. https://doi.org/10.1057/s41268-0180136-2

Brandwein, P. (2014). Studying the careers of knowledge claims: A guide. In D. Yanow \& P. Schwartz-Shea (Eds.), Interpretation and method: Empirical research methods and the interpretive turn (pp. 284-299). M. E. Sharpe.

Delputte, S., \& Orbie, J. (2020). Paradigm shift or reinventing the wheel? Towards a research agenda on change and continuity in EU development policy. Journal of Contemporary European Research, 16(2), 234-256. https://www.jcer.net/index.php/jcer/ article/view/1084

Elliott, V. (2018). Thinking about the coding process in qualitative data analysis. The Qualitative Report, 23(11), 2850-2861. https://doi.org/10.46743/2160$3715 / 2018.3560$

Escobar, A. (1997). Encountering development: The making and unmaking of the third world. Princeton University Press.

Escobar, A. (2015). Degrowth, postdevelopment, and transitions: A preliminary conversation. Sustainability Science, 10(3), 451-462. https://doi.org/10.1007/ s11625-015-0297-5 
European Commission. (2021). Trade policy reviewAn open, sustainable and assertive trade policy (COM(2021)66). https://trade.ec.europa.eu/doclib/ docs/2021/february/tradoc_159438.pdf

Garcia, M., \& Masselot, A. (2015). The value of gender equality in EU-Asian trade policy: An assessment of the EU's ability to implement its own legal obligations. In A. Björkdahl, N. Chaban, J. Leslie, \& A. Masselot (Eds.), Importing EU norms (pp. 191-209). Springer.

Gstöhl, S., \& De Bièvre, D. (2017). The trade policy of the European Union. Macmillan International Higher Education.

Haastrup, T. (2020). Critical perspectives on Africa's relationship with the European Union. In D. Bigo, T. Diez, E. Fanoulis, B. Rosamond, \& Y. A. Stivachtis (Eds.), The Routledge handbook of critical European Studies (pp. 511-522). Routledge.

Harrison, J., Barbu, M., Campling, L., Ebert, F. C., Martens, D., Marx, A., Orbie, J., Richardson, B., \& Smith, A. (2019). Labour standards provisions in EU free trade agreements: Reflections on the European Commission's reform agenda. World Trade Review, 18(4), 635-657. https://doi.org/10.1017/ S1474745618000204

Hickel, J. (2021). Less is more: How degrowth will save the world. Windmill Books.

Hoang, H., \& Sicurelli, D. (2017). The EU's preferential trade agreements with Singapore and Vietnam. Market vs. normative imperatives. Contemporary Politics, 23(4), 369-387. https://doi.org/10.1080/13569775. 2017.1289303

Horký-Hlucháň, O., \& Szent-Iványi, B. (2015). Neither security nor development? Czech and Hungarian identities and interests in the provincial reconstruction teams in Afghanistan. East European Politics, 31(4), 388-406. https://doi.org/10.1080/21599165. 2015.1078792

Keukeleire, S., \& Lecocq, S. (2018). Operationalising the decentring agenda: Analysing European foreign policy in a non-European and post-western world. Cooperation and Conflict, 53(2), 277-295. https://doi.org/ $10.1177 / 0010836718766394$

Kinnvall, C. (2016). The postcolonial has moved into Europe: Bordering, security and ethno-cultural belonging. Journal of Common Market Studies, 54(1), 152-168. https://doi.org/10.1111/jcms.12326

Kishore, P. (2017). A critical analysis of conditionalities in the generalized system of preferences. Canadian Yearbook of International Law/Annuaire canadien de droit international, 54, 98-133. https://doi.org/ 10.1017/cyl.2017.8

Koch, S. (2015). A typology of political conditionality beyond aid: Conceptual horizons based on lessons from the European Union. World Development, 75, 97-108. https://doi.org/10.1016/ j.worlddev.2015.01.006

Kothari, A., Salleh, A., Escobar, A., Demaria, F., \& Acosta, A. (2019). Pluriverse. A post-development dictionary.
Tulika Books.

Langan, M. (2020). Neo-colonialism, Nkrumah and AfricaEurope ties. In R. Rabaka (Ed.), Routledge handbook of pan-Africanism (pp. 101-111). Routledge.

Lincoln, D. (2008). Drawing the EBA (Everything but Arms) map: Least Developed Country classification and the case of EBA sugar. Area, 40(2), 218-227. https://www.jstor.org/stable/40346116

Martens, D., Van den Putte, L., Oehri, M., \& Orbie, J. (2018). Mapping variation of civil society involvement in EU trade agreements: A CSI index. European Foreign Affairs Review, 23(1), 41-62. http://hdl. handle.net/1854/LU-8565717

Matthews, S. (2004). Post-development theory and the question of alternatives: A view from Africa. Third World Quarterly, 25(2), 373-384. https://doi.org/ $10.1080 / 0143659042000174860$

Meissner, K. L. (2021). Requesting trade sanctions? The European Parliament and the Generalized Scheme of Preferences. Journal of Common Market Studies, 59(1), 91-107. https://doi.org/10.1111/jcms.13142

Merlingen, M. (2007). Everything is dangerous: A critique of "normative power Europe." Security Dialogue, 38(4), 435-453. https://doi.org/10.1177/ 0967010607084995

Murray-Evans, P. (2018). Power in North-South trade negotiations: Making the European Union's economic partnership agreements. Routledge.

Musliu, V. (2021). Europeanization and statebuilding as everyday practices: Performing Europe in the Western Balkans. Routledge.

Netherlands, \& France. (2020). Non-paper from the Netherlands and France on trade, social economic effects and sustainable development. https://www. permanentrepresentations.nl/documents/ publications/2020/05/08/non-paper-from-nl-and-fron-trade-social-economic-effects-and-sustainabledevelopment

Oehri, M. (2017). US and EU external labor governance: Workers' rights promotion in trade agreements and in practice. Springer.

Onar, N. F., \& Nicolaïdis, K. (2013). The decentring agenda: Europe as a post-colonial power. Cooperation and Conflict, 48(2), 283-303. https://doi.org/ $10.1177 / 0010836713485384$

Orbie, J. (2021a). EU trade policy meets geopolitics: What about trade justice? European Foreign Affairs Review, 26(2), 197-202. http://hdl.handle.net/1854/ LU-8707708

Orbie, J. (2021b). The graduation of EU development studies: Towards a post-colonial turn? Global Affairs, 7(4), 597-613. https://doi.org/10.1080/23340460. 2021.1999175

Orbie, J., \& Tortell, L. (2009). The new GSP+ beneficiaries: Ticking the box or truly consistent with ILO findings? European Foreign Affairs Review, 14(5), 663-681. http://hdl.handle.net/1854/LU-1092835

Pieterse, J. N. (2010). After post-development. Third 
World Quarterly, 21(2), 175-191. https://doi.org/ 10.1080/01436590050004300

Portela, C. (2010). European Union sanctions and foreign policy: When and why do they work? Routledge.

Portela, C. (2021). Trade preference suspensions as economic sanctions. In P. Van Bergeijk \& G. Ledda (Eds.), Research handbook on economic sanctions (pp. 264-279). Edward Elgar.

Rahnema, M., \& Bawtree, V. (1997). The postdevelopment reader. Zed Books.

Regulation (EU) No 978/2012 of the European Parliament and of the Council of 25 October 2012 applying a scheme of generalised tariff preferences and repealing Council Regulation (EC) No 732/2008. (2012). Official Journal of the European Union, L 303. https://eur-lex.europa.eu/legal-content/EN/ TXT/PDF/?uri=CELEX:32012R0978\&from=EN

Rutazibwa, O. U. (2010). The problematics of the EU's ethical (self) image in Africa: The EU as an "ethical intervener" and the 2007 joint Africa-EU strategy. Journal of Contemporary European Studies, 18(2), 209-228. https://doi.org/10.1080/14782804. 2010.486976

Sabaratnam, M. (2013). Avatars of Eurocentrism in the critique of the liberal peace. Security Dialogue, 44(3), 259-278. https://doi.org/10.1177/0967010613485 870

Sachs, W. (Ed.). (1992). The development dictionary. A guide to knowledge as power. Zed Books.

Schöneberg, J. (2016). Making development political. Nomos.

Schöneberg, J. (2021). Layers of post-development: De- and reconstructions in a world in which many worlds exist. (Working Paper Series No. 9). Uni- versity of Kassel. https://www.uni-kassel.de/fb05/ index.php?elD=dumpFile\& $t=f \& f=1269 \&$ token $=$ 9b0ca2ec9a38f26611344ecaf07846690504f9b9

Sebhatu, R. W. (2020). Applying postcolonial approaches to studies of Africa-EU relations. In T. Haastrup, L. Mah, \& N. Duggan (Eds.), The Routledge handbook of EU-Africa relations (pp. 38-50). Routledge.

Siles-Brügge, G. (2014). EU trade and development policy beyond the ACP: Subordinating developmental to commercial imperatives in the reform of GSP. Contemporary Politics, 20(1), 49-62. https://doi.org/ 10.1080/13569775.2014.881604

Staeger, U. (2016). Africa-EU relations and normative power Europe: A decolonial pan-African critique. Journal of Common Market Studies, 54(4), 981-998. https://doi.org/10.1111/jcms.12350

Van Roozendaal, G. (2017). Where symbolism prospers: An analysis of the impact on enabling rights of labour standards provisions in trade agreements with South Korea. Politics and Governance, 5(4), 19-29. https:// doi.org/10.17645/pag.v5i4.1087

Wardhaugh, B. (2013). GSP+ and human rights: Is the EU's approach the right one? Journal of International Economic Law, 16(4), 827-846. https://doi.org/ $10.1093 / \mathrm{jiel} / \mathrm{jgt031}$

Ziai, A. (2007). The ambivalence of post-development: Between reactionary populism and radical democracy. In A. Ziai (Ed.), Exploring post-development (pp. 121-138). Routledge.

Ziai, A. (2017). "I am not a post-developmentalist, but..." The influence of post-development on development studies. Third World Quarterly, 38(12), 2719-2734. https://doi.org/10.1080/01436597.2017.1328981

\section{About the Authors}

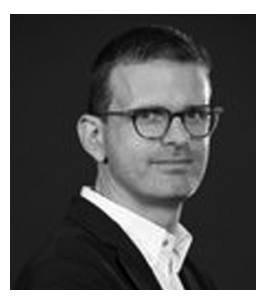

Jan Orbie is associate professor in European Union (EU) external relations at the Department of Political Science at Ghent University (Belgium). He is a member of the Ghent Institute for International and European Studies (GIES) and the Ghent Centre for Global Studies (GCGS) at the same university. He researches and teaches about the European Union's global role with a particular focus on critical and normative approaches to EU external trade, social, and development policies.

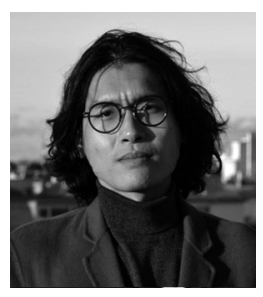

Antonio Salvador M. Alcazar III is a doctoral candidate in political science at Central European University (Austria) and a visiting research fellow at Institut Barcelona d'Estudis Internacionals (Spain). He is invested in critical/interpretivist approaches to EU trade relations with the global souths. He holds an M. A. in International Relations from Central European University (Hungary) and a B. A. in International and European Studies from De La Salle University (the Philippines).

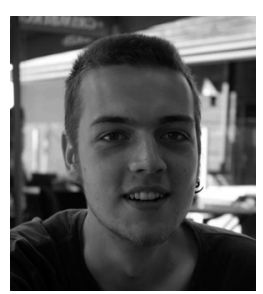

Tinus Sioen holds an M. A. degree in Comparative Modern Literature. He is currently affiliated with the Department of Political Science at Ghent University as a M. Sc. EU Studies student. He completed an internship at the Centre for EU Studies (CEUS) where he worked on EU trade policy. His other interests include populism, the radical right, and Gramscian thought. 